\section{HindIII/EcoRI polymorphism in the GAA gene}

L.H.Hoefsloot, M.Hoogeveen-Westerveld, H.Sakuraba', Y.Suzuki ${ }^{1}$, B.A.Oostra and A.J.J.Reuser*

MGC-Department of Cell Biology and Genetics, Erasmus University, PO Box 1738, 3000 DR Rotterdam, The Netherlands and ${ }^{1}$ Department of Clinical Genetics, The Tokyo Metropolitan Institute of Medical Science, Honkomagome, Bunkyo-ku, Tokyo 113, Japan

Source/Description: Full length cDNA coding for human lysosomal glucosidase alpha gene was cloned in the eukaryotic expression vector pSG5 (1). The $3.6 \mathrm{~kb}$ EcoRI insert was used as a probe.

Polymorphism: In HindIII/EcoRI digested DNA the probe recognises a three-allele polymorphism with fragments of 5.2 (A1), 4.6 (A2), or 3.1 and $1.5 \mathrm{~kb}$ (A3). Constant fragments are 12 and $9 \mathrm{~kb}$ (see figure).

Frequency: In 17 unrelated Caucasians and 24 Asians:

$\begin{array}{lll}\text { A1 } & \text { Caucasians } & \text { Asians } \\ \text { A2 } & - & 0.29 \\ \text { A3 } & 0.87 & 0.63 \\ & 0.13 & 0.08\end{array}$

Not Polymorphic For: PvuII, TaqI, RsaI, BclI, BamHI when tested in 18 individuals.

Chromosomal Localisation: 17q23.

Mendelian Inheritance: Co-dominant segregation of the A1 and A2 allele observed in three pedigrees.

Probe Availability: Contact A.J.J.Reuser.

Acknowledgements: The authors wish to thank Mirko Kuit for the artwork. Part of this work was financed by the Netherlands Organisation for Scientific Research (NWO) and by the Prinses Beatrix Fonds.

Reference: Hoefsloot,L.H. et al. (1988) EMBO J. 7, 1697-1704.

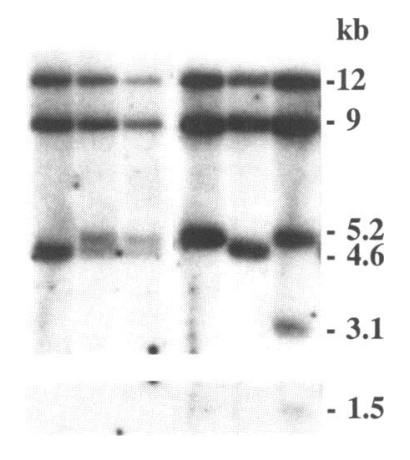

* To whom correspondence should be addressed

\section{Dinucleotide repeat polymorphism at the D11S35 locus}

M.Litt*, V.Sharma and J.A.Luty

Oregon Health Sciences University, Portland, OR 97201, USA

Source and Description: Phage 2-22 was from a human genomic library of CF52, a mouse X human somatic cell hybrid that retained a single translocated human chromosome, $t(11 ; 16)$ (q13;p11) on a rodent background (1). A Sau3A subclone of this phage that contained a $(G T)_{17}$ repeat was sequenced and sequences flanking the repeat (EMBL accession no. X52579) were used to design PCR primers.

PCR Primers:

(\# 780)-5'-ACAATTGGATTACTACTAGC-3'

(\# 781)-5'-TGTATTTGTATCGATTAACC-3'

Polymorphism: Allelic fragments were resolved on DNA sequencing gels. Lengths of allelic fragments (nt) were: $A 1=162$, $\mathrm{A} 2=160, \mathrm{~A} 3=158, \mathrm{~A} 4=156, \mathrm{~A} 5=154, \mathrm{~A} 6=152$.

Frequencies: Allele frequencies in 17 unrelated European Caucasians: $\mathrm{A} 1=.12, \mathrm{~A} 2=.26, \mathrm{~A} 3=.15, \mathrm{~A} 4=.12, \mathrm{~A} 5=.18$, $\mathrm{A} 6=.18$. Heterozygosity $=0.88 ; \mathrm{PIC}=0.79$.

Chromosomal Localization and Mendelian Inheritance: In situ hybridization and hybridization of phage 2-22 to genomic DNAs from a somatic cell hybrid panel indicated localization to $11 \mathrm{q} 22$ (1). Linkage analysis of the D11S35 MspI RFLP in CEPH families supports the order cen-D11S84-D11S35-D11S424-qter (2). Mendelian inheritance was observed in three informative families with a total of 23 children.

PCR Conditions: We carry out PCR in a total volume of $25 \mu \mathrm{l}$ containing: $50 \mathrm{ng}$ genomic DNA, 25 pmoles of each primer, 1.5 $\mathrm{mM} \mathrm{MgCl} 2,200 \mu \mathrm{M}$ unlabeled dNTPs, $50 \mathrm{mM} \mathrm{KCl,} 10 \mathrm{mM}$ Tris- $\mathrm{Cl}^{-}$, pH 8.3, 0.6 units Taq polymerase (PerkinElmer/Cetus) and $0.01 \%$ gelatin. $1 \mu \mathrm{Ci}\left[{ }^{32} \mathrm{P}\right] \mathrm{dCTP}$ is added to each sample. Amplification is for 30 cycles with denaturation at $93^{\circ} \mathrm{C}$ for $1 \mathrm{~min}$, annealing at $40^{\circ} \mathrm{C}$ for $2 \mathrm{~min}$ and extension at $72^{\circ} \mathrm{C}$ for $2 \mathrm{~min}$. Products are resolved on DNA sequencing gels and visualized by autoradiography.

Acknowledgements: This work was supported by Grant GM-32500 from the National Institutes of Health.

References: 1) Maslen,C.L., Jones,C., Glaser,T., Magenis,R.E., Sheehy,R., Kellogg,J. and Litt,M. (1988) Genomics 2, 66-75. 2) Julier,C., Nakamura,Y., Lathrop,M., O'Connell,P., Leppert,M., Litt,M., Mohandas,T., Lalouel,J.-M. and White,R. (1990) Genomics 7, 335-345.

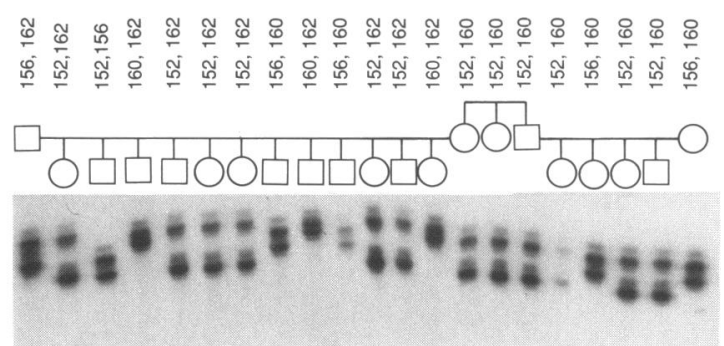

\footnotetext{
* To whom correspondence should be addressed
} 